\title{
A Brief Comment on the Interpretation of Humboldt
}

\author{
Henning Schluß (University of Vienna)
}

\begin{abstract}
:
Giesinger's assessment is based on a misunderstanding. Humboldt develops his construction precisely not with respect to the liberal state, but to the monarchic and absolutist state. Democratic states, according to Humboldt, both in antiquity and in his own days, have certainly intervened into individual education and limited liberties.
\end{abstract}

Keywords:

reply

Johannes Giesinger writes:

A radical account of the independence of education was developed by Wilhelm von Humboldt (1980). In an early work on the outlines of the liberal state, Humboldt claimed that education should not be under state control. He thought that the state would inevitably use the education system for its own purposes, and try to create useful citizens, instead of promoting 'humanity' (Giesinger, 2018, p. 1)

This assessment is based on a misunderstanding. Humboldt develops his construction precisely not with respect to the liberal state, but to the monarchic and absolutist state. Democratic states, according to Humboldt, both in antiquity and in his own days, have certainly intervened into individual education and limited liberties.

In the ancient States, almost all the institutions relating to the private life of the citizens were of a strictly political character. Possessed, as it was, of but little absolute authority, the constitution was mainly dependent for its duration on the will of the nation, and hence it was necessary to discover or propose means by which due harmony might be preserved between the character of established institutions and this tendency of national feeling. The same policy is still observable in small republican States; and if we were to regard it in the light of these circumstances alone, we might accept it as true, that the freedom of private life always increases in exact proportion as public freedom declines; whereas security always keeps pace with the latter (Humboldt, 1792, p. 10).

Humboldt's argument is that these limitations of liberty of the individual are less illegitimate in republics where citizens rule themselves. Insofar as citizens partially relinquish their liberty to the sovereign, who is partly identical with themselves, this is less problematic, because it is themselves who at least indirectly also have a say in their own education and that of their children. This is different in monarchic or absolutist states. In these cases, the state is not allowed to intervene into the individual realm, which, among others, includes the realm of education. Instead, it has to remain a night watchman state, only in charge of safeguarding inner and outer security.

It has, of late, been usual to insist on the expediency and propriety of preventing illegal actions, and of calling in the aid of moral means to accomplish such a purpose; but I will not disguise that, when I hear such exhortations, I am satisfied to think such encroachments on freedom are becoming more rare among us, and in almost all modern constitutions daily less possible. It is not uncommon to appeal to the history of Greece and Rome in support of such a policy; but a clearer insight into the nature of the constitutions of those ancient nations would at once betray the inconclusiveness of such comparisons. Those States were essentially republics; and such kindred institutions as we find in them were pillars of the free constitution, and were regarded by the citizens with an enthusiasm which rendered their hurtful restrictions on private freedom less deeply felt, and their energetic character less pernicious. They enjoyed, moreover, a much wider range of freedom than is usual among modern States, and anything that was sacrificed was only given up to another form of activity, viz. participation in the affairs of government. Now, in our States, which are in general monarchical, all this is necessarily changed (Humboldt, 1792, p. 40).

The implication of this for Johannes Giesinger's argument is worth considering. Based on Humboldt's early work (the "green book", as he called it), one may at any rate argue that - from Humboldt's perspective - in the context of democratic states, the state could be allowed to 
play a bigger role in the educational system. Citizens in democratic states participate in the control of public education and thus do not delegate power to a state entirely beyond their control and influence.

The strengthening of the private sector in the educational system by the Trump administration admittedly would be acceptable for Humboldt in the case of monarchic states. Insofar as the USA regards itself as a democracy, a bigger role of the state in public education could be justified based on Humboldt's position. The question remains, however, as to what extent these premises actually apply in the case of the current educational and political system of the USA. Moreover, it is another question whether we still share Humboldt's premises today.

It is telling that the more Prussia renewed itself and at least temporarily turned away from absolutist principles after the Napoleonic Wars and the inevitable reforms that went along with them, the more Humboldt himself was ready to participate in the state's administration of the educational system. This also holds with regard to his readiness to publicly defend the claim that his ideal of a manifold 'Bildung' should also be realized in state-run public schools (see his 'Königsberger' and 'Litauischer Schulplan').

At any rate, one may deduce from Humboldt's 'Ideenschrift' that in the case of absolutist states, an educational system that is to the greatest possible extent independent from the state is crucial in order to safeguard the liberty of citizens. In light of contemporary trends towards autocratic systems in Europe, it is worth considering how the claims of the public can be maintained in the educational system. Furthermore, we should rethink whether the established assumption, that state control of the educational system automatically implies that the educational system should be public, is still up to date in present circumstances. Last but not least, perhaps we should be reminiscent of the classical Enlightenment positions according to which the public was an achievement that was primarily gained and defended against the state. This is true also and especially in the field of education (see Schluß, 2017).

\section{References}

Giesinger, J. (2018). The independence of education. On Education. Journal for Research and Debate, 1(1). https://doi.org/10.17899/on_ed.2018.1.4

Humboldt, W. von. (1792). The sphere and duties of government (J. Coulthard, Trans.; 1854 ed.). John Chapman. https://oll.libertyfund.org/title/coulthard-the-sphere-and-duties-of-government-1792-1854

Schluß, H. (2017). "Öffentlichkeit" - Rekonstruktion eines Grundbegriffs von Pädagogik und Theologie. In K. Baur \& D. Oesselmann (Eds.), Religiöse Divergenz und Pluralitätskompetenz - Eine Herausforderung für das Lernen, Lehren und Forschen an Hochschulen und Bildungseinrichtungen (pp. 81-107). Lit-Verlag.

\section{Recommended Citation}

Schluß, H. (2018). A brief comment on the interpretation of Humboldt. On Education. Journal for Research and Debate, 1(1). https://doi.org/10.17899/on_ed.2018.1.9

About the Author

Henning Schluß is Professor of Educational Theory and Empirical Education Research at the University of Vienna. 